\title{
Peranan Guru dalam Menangani Perilaku Bullying Siswa di SMPN 2 Tinambung Kecamatan Balanipa Kabupaten Polewali Mandar
}

\author{
Andi Sugiati ${ }^{1)}$, Jumiati Nur ${ }^{2}$ \& Salma Arizanti) \\ Pendidikan Pancasila dan Kewarganegaraan FKIP Universitas Muhammadiyah Makassar ${ }^{1)}$ \\ Pendidikan Pancasila dan Kewarganegaraan FKIP Universitas Muhammadiyah Makassar ${ }^{2)}$ \\ Pendidikan Pancasila dan Kewarganegaraan FKIP Universitas Muhammadiyah Makassar ${ }^{3)}$

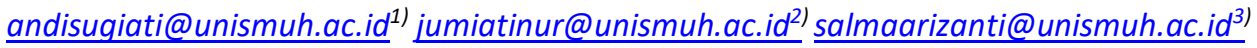

\begin{abstract}
The main problem in this research is how the role of PPKn teachers in dealing with students' bullying behavior at Tinambung 2 Public High School in Pambusuang District, Polewali Mandar District, West Sulawesi Province. This study aims to determine the role of PPKn teachers in dealing with students' bullying behavior at Tinambung 2 Public High School in Pambusuang District, Polewali Mandar District, West Sulawesi Province. This type of research is an experiment consisting of two variables where there is a test given to the control class (before treatment) and the experimental class (after treatment). The method of data collection consists of three ways, namely: questionnaire, interview and documentation. The sample in this study was class VIII students. C and class VIII.D as many as 25 people each class. The results of the study show that, from the results of the independent test T-test samples ( $t$ test) it is known that the significance value of $0.123 \geq 0.05$, there is a significant value between the control class (before treatment) and the experimental class (after treatment). So to test the hypothesis it can be seen from the significance of two tailled, namely Ho is accepted if sig. 2 tailled $\geq 0.05$ and Ho is rejected if sig. 2 tailled $\leq 0.05$. So the hypothesis of this study was accepted because the value of sig 2 tailled $\geq 0.05$ is $(0.123 \geq 0.05)$. So in this study the role of PPKn teachers in handling bullying behaviors of students at Tinambung 2 Public High School was done.
\end{abstract}

Keywords : Role, teacher, Bullying behavior

\begin{abstract}
Abstrak. Masalah utama dalam penelitian in i yaitu bagaimana Peranan Guru PPKn Dalam Menangani Perilaku Bullying Siswa di SMPN 2 Tinambung Kecamatan Pambusuang Kabupaten Polewali Mandar Provinsi Sulawesi Barat. Penelitian ini bertujuan untuk mengetahui Peranan Guru PPKn Dalam Menangani Perilaku Bullying Siswa di SMPN 2 Tinambung Kecamatan Pambusuang Kabupaten Polewali Mandar Provinsi Sulawesi Barat. Jenis penelitian ini adalah eksperimen yang terdiri dari dua variable dimana Terdapat pemberian test kepadaa kelas control (sebelum perlakuan) dan kelas eksperimen (sesudah perlakuan). Metode pengumpulan data terdiri atas tiga cara yaitu: angket, wawancara dan dokumentasi. Yang menjadi sampel dalam penelitian ini adalah siswa kelas VIII. C dan kelas VIII.D sebanyak 25 orang masing-masing kelas. Hasil Penelitian menunjukkan bahwa, dari hasil uji independen Sampel T-test (uji t) diketahui bahwa nilai signifikasi $0.123 \geq 0.05$, maka terdapat nilai yang signifikan antara kelas control (sebelum perlakuan) dengan kelas eksperimen (sesudah perlakuan). Sehingga untuk menguji hipotesis maka dapat dilihat dari nilai signifikasi 2 tailled yaitu Ho diterima jika sig. 2 tailled $\geq 0.05$ dan Ho ditolak jika sig. 2 tailled $\leq$ 0.05. Jadi hipotesis dari penelitian ini Ho diterima karena nilai sig 2 tailled $\geq 0.05$ yaitu $(0.123 \geq 0.05)$. Maka pada penelitian ini terdapa peranan guru PPKn dalam menangani perilaku bullying siswa di SMPN 2 Tinambung.
\end{abstract}

Kata kunci: Peranan, guru, Perilaku Bullying 


\section{PENDAHULUAN}

Pendidikan adalah salah satu factor utama dalam mencetak generasi penerus bangsa yang berkualitas. Pendidikan merupakan usaha sadar yang dengan sengaja direncanakan untuk mencapai tujuan yang ditetapkan.Untuk memperbaiki dan meningkatkan mutu pendidikan perlu dilakukan berbagai usaha. Dalam hal ini dapat terwujud di sekolah, yang di sana terjadi interaksi antara guru dan siswa.

Seorang guru yang produktifitas sangat diperlukan untuk membentuk siswa kearah kemajuan supaya berguna dan bermanfaat bagi Nusa dan Bangsa. Masalah itu diantaranya adalah "School Bullying". "School Bullying" saat ini sangat memprihatinkan bagi pendidik, orang tua, dan masyarakat. Sekolah yang seharusnya menjadi tempat bagi anak untuk menimba ilmu dan membantu karakter pribadi yang cerdas, kritis, kreatif dan inovatif ternyata malah menjadi sekolah yang tumbuhnya praktik-praktik bullying.

School bullying adalah perlakuan tidak menyenangkan yang dialami oleh siswa di sekolah. Pelaku school bullying pada umumnya teman sebaya, siswa yang lebih senior, atau bahkan guru. School bullying muncul akibat adanya pelanggaran yang disertai penghukuman, terutama fisik, akibat buruknya system dan kebijakan pendidikan yang berlaku. Praktik School Bullying sebagai bentuk kekerasan di institusi pendidikan biasa dilakukan oleh siapa saja, baik antar teman, antar siswa, antar geng di sekolah, kakak kelas bahkan guru. Lokasi kejadiaannya mulai dari ruang kelas, toilet, kantin, halaman, pintu gerbang bahkan di luar pagar sekolah. Akibatnya, sekolah bukan lagi menjadi tempat yang menyenangkan bagi siswa, melainkan justru neraka, tempat yang menakutkan dan membuat trauma. Selain itu school bullying memberi banyak sekali dampak buruk kepada siswa yang menjadi korban, yang secara structural menyebabkan kemunduran pendidikan nasional. Korban school bullying tidak hanya menderita ketakutan di sekolah saja, bahkan kasus school bullying menjadi masalah fundamental untuk segera diatasi.
Bullying terkadang sangat halus sehingga kita tidak sadar telah menjadi korbannya. Bahkan, bisa jadi pelaku bullying sendiri tidak menyadari bahwa dia telah melakukan tindakan bullying. Salah satu tindakan bullying diantaranya adalah perkataanperkataan kasar, panggilan-panggilan buruk untuk seseorang tindakan ini merupakan salah satu tindakan bullying yang sering terjadi di masyarakat Indonesia dan dianggap sebagai alat komunikasi yang wajar.

\section{METODE PENELITIAN}

Jenis penelitian yang digunakan dalam penelitian ini adalah Non-equivalent Control Group Design. Desain ini hamper sama dengan Pretestposttest Group Design, hanya pada desain ini kelompok eksperimen maupun kelompok control tidak dipilih secara random. Pada kedua kelompok tersebut akan dilakukan pengukuran sebanyak dua kali, yaitu sebelum dan sesudah perlakuan. Pertama dilakukan pengamatan awal, kemudian pada kelompok eksperimen diberikan perlakuan, namun pada kelompok control tidak diberikan perlakuan seperti pada kelompok eksperimen. Selanjutnya akan dilakukan kembali pengukuran guna melihat ada atau tidaknya pengaruh perlakuan yang telah diberikanterhadap subjek yang diteliti.

Populasi adalah wilayah generalisasi yang terdiri atas: obyek/subyek yang mempunyai kualitas dan karakteristik tertentu ditetapkan oleh peneliti untuk dipelajari dan kemudian ditarik kesimpulannya. Dalam penelitian ini, populasinya adalah Seluruh siswa di SMPN 2 tinambung Kec. Pambusuang Kab. Polewali mandar Prov. Sulawesi barat. Dalam hal ini sampel penelitiannya adalah siswa di SMPN 2 tinambung Kec. Pambusuang Kab. Polewali mandar Prov. Sulawesi barat, yaitu kelas VIII. C sebagai kelas eksperimen sebanyak 25 siswa dan kelas VIII. D sebagai kelas control sebanyak 25 siswa. Alasan peneliti memilih kedua kelas tersebut di karenakan kedua kelas ini memiliki jam pelajaran yang sama pada saat pembelajaran PPKn.

Teknik pengambilan sampel yang dipilih oleh peneliti adalah teknik non probability sampling. Sugiyono (2017;18), membagi teknik non probability sampling menjadi beberapa jenis antara lain sampling sistematis, kuota incidental,purposive, jenuh dan snowball. Dalam penelitian ini penulis menetapkan jenis pengambilan sampel penelitian yaitu sampling 
purposive. Teknik penentuan sampel ini dengan pertimbangan tertentu yang disarankan oleh guru PPKn lokasi tempat penelitian dilaksanakan.

Dalam penelitian ini, variable penelitiannya terdapat satu maka jumlah instrument yang digunakan untuk penelitian juga satu. Instrument penelitian adalah alat bantu bagi peneliti dalam mengumpulkan data. Adapun instrument dalam penelitian ini adalah:

1. Kuesioner atau angket sebagai instrument penelitian berisi pertanyaan atau pernyataan yang mewakili aspek yang akan diteliti.

2. Kamera, sebagai alat untuk mendokumentasikan kegiatan yang dilakukan di lapangan penelitian berlangsung.

3. Catatan yang dipakai oleh peneliti dalam mencatat hal-hal penting selama penelitian berlangsung.

Salah satu instrument yang digunakan penulis yaitu angket/kuesioner, merupakan seperangkat pertanyaan atau pernyataan yang berbentuk tulisan diberikan oleh peneliti kepada responden untuk memperoleh data dimana setiap variable penelitian dengan menggunakan skala Likert, skala Likert digunakan untuk mengukur sikap, pendapat, dan persepsi seseorang atau sekelompok tentang fenomena social.

Analisis data adalah proses mencari dan menyusun secara sistematis yang diperoleh dari hasil angket, tes, wawancara, dan dokumentasi. Analisis data dilakukan dengan cara mengorganisasikan data kedalam kategori, menjabarkan kedalam unit-unit, melakukan sintesa, menyusun pola, memilih mana yang penting dari mana yang akan dipelajari dan membuat kesimpulan sehingga dengan mudah dipahami oleh diri sendiri maupun orang lain. Untuk mengetahui keberhasilan eksperimen, adanya peranan guru PPKn dalam menangani perilaku Bullying siswa dapat digunakan rumus uji $t$ atau independent sampel T-test yang digunakan untuk menguji hipotesis komperatif dua variabel, analisis data ini menggunakan bantuan program SPSS (statitistikal product and service solution)versi 11.5 Adapun rumus uji t tidak berkolerasi adalah sebagai berikut

$$
\begin{aligned}
\mathrm{T}_{\text {hitung }} & =\frac{\overline{\mathrm{X}}_{1-}-\overline{\mathrm{X}}_{2}}{\frac{\sqrt{\left(\mathrm{n}_{1}-1\right) \mathrm{s}_{1}^{2}+\left(\mathrm{n}_{1}-1\right) \mathrm{s}_{\mathrm{s}}^{2}}}{\left(\mathrm{n}_{1}+\mathrm{n}_{2}-2\right)} \frac{1+1}{\mathrm{n}_{1} \mathrm{n}_{2}}} \\
\mathrm{~T}_{\text {tabel }} & =\mathrm{t}\left(\alpha, \mathrm{n}_{1}+\mathrm{n}_{2}-2\right) \\
\text { Keterangan } & \\
\overline{\mathrm{X}}_{1}: \text { rata } & \text { rata sampel } 1 \\
\overline{\mathrm{X}}_{2}: \text { rata } & - \text { rata sampel } 2
\end{aligned}
$$

$\mathrm{n}_{1}$ : banyaknya data sampel 1

$\mathrm{n}_{2}$ : banyaknya data sampel 2

$\mathrm{s}_{1}$ : simpangan baku sampel 1

$\mathrm{s}_{2}$ : simpangan baku sampel 2

Berdasarkan nilai tersebut aka diperoleh nilai t hitung signifikan atau tidak, konsultasikan dengan table $\mathrm{t}$, dengan $\mathrm{df}=\mathrm{n}-2$ jila nilai $\mathrm{t}$ hitung $\geq \mathrm{t}$ table maka signifikan, dan sebaliknya jika nilai $t$ hitung $\leq \mathrm{t}$ table maka tidak signifikan

Uji normalitas merupakan salah satu bagian dari uji persyaratan analisis data artinya sebelum kita melakukan analisis yang sesungguhnya, data penelititan tersebut harus di uji kenormalan distribusinya. Dasar pengambilan keputusan dalam uji normalitas yaitu :

- Jika sig. $\geq 0.05$ maka data tersebut normal

- Jika sig $\leq 0.05$ maka data tersebut tidak normal.

a. Uji independent sampel $T$ test

Independen $\mathrm{T}$ test jika diterjemahkan dalam bahasa Indonesia maka berarti uji t sampel tidak berhubungan atau bebas. Perhatikan kata "independen" atau "bebas" maknanya adalah tidak ada hubungan antara dua sampel yang akan diuji. Dalam penelitian ini ada dua rata-rata sampel yang terdiri dari kelas ekperimen dan kelas control terkait Peranan Guru PPKn.

- Jika nilai signifikansi $\geq 0.05$, maka Ho diterima dan Ha ditolak.

- Jika nilai signifikansi $\leq 0.05$, maka Ho ditolak dan Ha diterima.

\section{PEMBAHASAN}

Penelitian ini termasuk penelitian eksperimen. Data penelitian terdiri dari tes awal dan tes akhir tentang peranan guru PPKn dalam menangani perilaku bullying siswa di SMPN 2 Tinambung. Penelitian dilaksanakan tanggal 09 juli - 30 agustus 2081. Pemberian perlakuan dilaksanakan pada hari kamis jam ke 5 - 7 di kelas VIIII C sebagai kelas eksperimen dan selasa jam ke 5 - 7 di kelas VIIII D sebagai kelas control.

Penelitian ini mengangkat satu variable penelitian yaitu variable bebas peranan guru PPKn dalam menangani perilaku bullying. Data siswa diperoleh dengan tes berbentuk skala likert. Dalam penelitian ini, peneliti memperoleh data dari hasil test kepada kelas control sebelum perlakuan dan test juga dilakukan pada kelas eksperimen sesuadah diberikan perlakuan. Kedua test ini berfungsi untuk mengukur sampai dimana peranan guru PPKn dalam menjalankan perannya dalam menangani perilaku bullying di SMPN 2 Tinambung. 
Sebelum data diuji signifikasinya, terlebih dahulu peneliti akan menginterpretasikan skor yang diperoleh oleh objektif dengan data berskala likert.

Nilai frekuensi test Kelas control sebelum perlakuan Frekuensi test (Bullying fisik) pada Kelas control sebelum perlakuan

Table 1 Frekuensi test bullying fisik pada( kelas kontrol)

\begin{tabular}{|c|c|c|c|c|}
\hline No & Uraian & Skor & Frekuensi & Persentase \\
\hline 1 & Tidak Pernah & 1 & 2 & $8 \%$ \\
\hline 2 & Jarang & 2 & 13 & $52 \%$ \\
\hline 3 & $\begin{array}{c}\text { Kadang- } \\
\text { Kadang }\end{array}$ & 3 & 6 & $24 \%$ \\
\hline 4 & Sering & 4 & 4 & $16 \%$ \\
\hline 5 & Sangat Sering & 5 & - & - \\
\hline \multicolumn{3}{|c|}{ Total } & 25 & $100 \%$ \\
\hline
\end{tabular}

Dari tabel di atas, maka diketahui bahwa dari 1 item pertanyaan mengenai Bullying Fisik dari 25 responden yang diberi kuesioner di kelas control yaitu; Terdapat 2 atau (8\%) responden yang menyatakan tidak pernah melakukan perilaku Bullying Fisik, 13 atau (52\%) responden yang menyatakan Jarang melakukan perilaku Bullying Fisik, 6 atau (24\%) responden yang menyatakan kadang - kadang melakukan perilaku Bullying Fisik, 4 atau (16\%) responden yang menyatakan sering melakukan perilaku Bullying Fisik dan Tidak ada responden yang menyatakan sangat sering melakukan perilaku bullying fisik.

Frekuensi test (Bullying verbal) pada Kelas control sebelum perlakuan

Table 6 Frekuensi test bullying verbal pada( kelas kontrol)

\begin{tabular}{|c|c|c|c|c|}
\hline No & Uraian & Skor & Frekuensi & Persentase \\
\hline 1 & Tidak Pernah & 1 & 18 & $72 \%$ \\
\hline 2 & Jarang & 2 & 3 & $12 \%$ \\
\hline 3 & $\begin{array}{c}\text { Kadang- } \\
\text { Kadang }\end{array}$ & 3 & 4 & $16 \%$ \\
\hline 4 & Sering & 4 & - & - \\
\hline 5 & Sangat Sering & 5 & - & - \\
\hline \multicolumn{3}{|c|}{ Total } & 25 & $100 \%$ \\
\hline
\end{tabular}

Dari table di atas, maka diketahui bahwa dari 1 item pertanyaan mengenai Bullying verbal dari 25 responden yang diberi kuesioner di kelas control yaitu; Terdapat 7 atau (28\%) responden yang menyatakan tidak pernah melakukan perilaku Bullying verbal, 9 atau (36\%) responden yang menyatakan Jarang melakukan perilaku Bullying verbal, 8 atau (32\%) responden yang menyatakan kadang - kadang melakukan perilaku Bullying verbal, 1 atau (4\%) responden yang menyatakan sering melakukan perilaku Bullying verbal dan Tidak ada responden yang menyatakan sangat sering melakukan perilaku Bullying verbal.

Frekuensi test (Bullying relasional) pada Kelas control sebelum perlakuan

Table 3 Frekuensi test bullying relasional pada( kelas kontrol)

\begin{tabular}{|c|c|c|c|c|}
\hline No & Uraian & Skor & Frekuensi & Persentase \\
\hline 1 & Tidak Pernah & 1 & 7 & $28 \%$ \\
\hline 2 & Jarang & 2 & 9 & $36 \%$ \\
\hline 3 & $\begin{array}{l}\text { Kadang- } \\
\text { Kadang }\end{array}$ & 3 & 8 & $32 \%$ \\
\hline 4 & Sering & 4 & 1 & $4 \%$ \\
\hline 5 & Sangat Sering & 5 & - & - \\
\hline \multicolumn{3}{|c|}{ Total } & 25 & $100 \%$ \\
\hline
\end{tabular}

Dari tabel di atas, maka diketahui bahwa dari 1 item pertanyaan mengenai Bullying relasional dari 25 responden yang diberi kuesioner di kelas control yaitu; Terdapat 18 atau (72\%) responden yang menyatakan tidak pernah melakukan perilaku Bullying relasional, 3 atau (12\%) responden yang menyatakan Jarang melakukan perilaku Bullying relasional, 4 atau (16\%) responden yang menyatakan kadang - kadang melakukan perilaku Bullying relasional, tidak ada responden yang menyatakan sering dan sangat sering melakukan perilaku Bullying relasional.

Frekuensi test (cyber bullying) pada Kelas control sebelum perlakuan

\section{Table 8}

Frekuensi test cyber bullying pada( kelas kontrol)

\begin{tabular}{|c|c|c|c|c|}
\hline No & Uraian & Skor & Frekuensi & Persentase \\
\hline 1 & Tidak Pernah & 1 & 13 & $52 \%$ \\
\hline 2 & Jarang & 2 & 5 & $20 \%$ \\
\hline 3 & $\begin{array}{l}\text { Kadang- } \\
\text { Kadang }\end{array}$ & 3 & 7 & $28 \%$ \\
\hline 4 & Sering & 4 & - & - \\
\hline 5 & Sangat Sering & 5 & - & - \\
\hline \multicolumn{3}{|c|}{ Total } & 25 & $100 \%$ \\
\hline
\end{tabular}

Dari tabel di atas, maka diketahui bahwa dari 1 item pertanyaan mengenai cyber bullying dari 25 responden yang diberi kuesioner di kelas control yaitu; Terdapat 13 atau (52\%) responden yang menyatakan tidak pernah melakukan perilaku cyber bullying, 5 atau (20\%) responden yang menyatakan Jarang melakukan perilaku cyber bullying, 7 atau (28\%) responden yang menyatakan kadang kadang melakukan perilaku cyber bullying, dan tidak ada responden yang menyatakan sering dan sangat sering melakukan perilaku cyber bullying. 
Frekuensi test (Bullying fisik) pada kelas ekperimen sesudah perlakuan

Frekuensi test (Bullying fisik) pada kelas eksperimen sesudah perlakuan

Table 4 Frekuensi test bullying fisik pada( kelas ekperimen)

\begin{tabular}{|c|c|c|c|c|}
\hline No & Uraian & Skor & Frekuensi & Persentase \\
\hline 1 & Tidak Pernah & 1 & 8 & $32 \%$ \\
\hline 2 & Jarang & 2 & 9 & $36 \%$ \\
\hline 3 & $\begin{array}{l}\text { Kadang- } \\
\text { Kadang }\end{array}$ & 3 & 4 & $16 \%$ \\
\hline 4 & Sering & 4 & 2 & $8 \%$ \\
\hline 5 & Sangat Sering & 5 & 2 & $8 \%$ \\
\hline \multicolumn{3}{|c|}{ Total } & 25 & $100 \%$ \\
\hline
\end{tabular}

Dari table di atas, maka diketahui bahwa dari 1 item pertanyaan mengenai Bullying Fisik dari 25 responden yang diberi kuesioner di kelas control yaitu; Terdapat 8 atau (32\%) responden yang menyatakan tidak pernah melakukan perilaku Bullying Fisik, 9 atau (36\%) responden yang menyatakan Jarang melakukan perilaku Bullying Fisik, 4 atau (16\%) responden yang menyatakan kadang - kadang melakukan perilaku Bullying Fisik, 2 atau (8\%) responden yang menyatakan sering melakukan perilaku Bullying Fisik dan 2 atau (8\%) responden yang menyatakan sangat sering melakukan perilaku bullying fisik.

Frekuensi test (Bullying verbal) pada kelas ekperimen sesudah perlakuan

Table 5 Frekuensi test bullying verbal pada( kelas ekperimen)

\begin{tabular}{|c|c|c|c|c|}
\hline No & Uraian & Skor & Frekuensi & Persentase \\
\hline 1 & Tidak Pernah & 1 & 6 & $24 \%$ \\
\hline 2 & Jarang & 2 & 17 & $68 \%$ \\
\hline 3 & $\begin{array}{l}\text { Kadang- } \\
\text { Kadang }\end{array}$ & 3 & 2 & $8 \%$ \\
\hline 4 & Sering & 4 & - & - \\
\hline 5 & Sangat Sering & 5 & - & - \\
\hline \multicolumn{3}{|c|}{ Total } & 25 & $100 \%$ \\
\hline
\end{tabular}

Dari table di atas, maka diketahui bahwa dari 1 item pertanyaan mengenai Bullying verbal dari 25 responden yang diberi kuesioner di kelas control yaitu; Terdapat 6 atau (24\%) responden yang menyatakan tidak pernah melakukan perilaku Bullying verbal, 17 atau (68\%) responden yang menyatakan Jarang melakukan perilaku Bullying verbal, 2 atau $(8 \%)$ responden yang menyatakan kadang - kadang melakukan perilaku Bullying verbal, dan Tidak ada responden yang menyatakan sering dan sangat sering melakukan perilaku Bullying verbal.
Frekuensi test (Bullying relasional) pada kelas ekperimen sesudah perlakuan

Table 6 Frekuensi test bullying relasional pada( kelas eksperimen)

\begin{tabular}{|c|c|c|c|c|}
\hline No & Uraian & Skor & Frekuensi & Persentase \\
\hline 1 & $\begin{array}{c}\text { Tidak } \\
\text { Pernah }\end{array}$ & 1 & 17 & $68 \%$ \\
\hline 2 & Jarang & 2 & 5 & $20 \%$ \\
\hline 3 & $\begin{array}{l}\text { Kadang- } \\
\text { Kadang }\end{array}$ & 3 & 3 & $12 \%$ \\
\hline 4 & Sering & 4 & - & - \\
\hline 5 & $\begin{array}{l}\text { Sangat } \\
\text { Sering }\end{array}$ & 5 & - & - \\
\hline \multicolumn{3}{|c|}{ Total } & 25 & $100 \%$ \\
\hline
\end{tabular}

Dari table di atas, maka diketahui bahwa dari 1 item pertanyaan mengenai Bullying relasional dari 25 responden yang diberi kuesioner di kelas control yaitu; Terdapat 17 atau (68\%) responden yang menyatakan tidak pernah melakukan perilaku Bullying relasional, 5 atau (20\%) responden yang menyatakan Jarang melakukan perilaku Bullying relasional, 3 atau (12\%) responden yang menyatakan kadang - kadang melakukan perilaku Bullying relasional, tidak ada responden yang menyatakan sering dan sangat sering melakukan perilaku Bullying relasional.

Frekuensi test (cyber bullying) pada kelas ekperimen sesudah perlakuan

Table 7 Frekuensi test cyber bullying pada( kelas eksperimen)

\begin{tabular}{|c|c|c|c|c|}
\hline No & Uraian & Skor & Frekuensi & Persentase \\
\hline 1 & Tidak Pernah & 1 & 15 & $60 \%$ \\
\hline 2 & Jarang & 2 & 8 & $32 \%$ \\
\hline 3 & $\begin{array}{l}\text { Kadang- } \\
\text { Kadang }\end{array}$ & 3 & 2 & $8 \%$ \\
\hline 4 & Sering & 4 & - & - \\
\hline 5 & Sangat Sering & 5 & - & - \\
\hline \multicolumn{3}{|c|}{ Total } & 25 & $100 \%$ \\
\hline
\end{tabular}

Dari table di atas, maka diketahui bahwa dari 1 item pertanyaan mengenai cyber bullying dari 25 responden yang diberi kuesioner di kelas control yaitu; Terdapat 15 atau (60\%) responden yang menyatakan tidak pernah melakukan perilaku cyber bullying, 8 atau (60\%) responden yang menyatakan Jarang melakukan perilaku cyber bullying, 2 atau (8\%) responden yang menyatakan kadang - kadang melakukan perilaku cyber bullying, dan tidak ada responden yang menyatakan sering dan sangat sering melakukan perilaku cyber bullying.

\section{Pengujian validitas}

Uji normalitas

Table 8 (One-Sample Kolmogorov-Smirnov Test) 


\begin{tabular}{|l|l|l|}
\hline \multicolumn{2}{|c|}{$\mathbf{N}$} & $\begin{array}{l}\text { Kelas } \\
\text { eksperimen }\end{array}$ \\
\cline { 3 - 3 } \multicolumn{2}{|c|}{} & 25 \\
\hline $\begin{array}{l}\text { Normal } \\
\text { Parameters(a,b) }\end{array}$ & Mean & 7.0000 \\
\cline { 2 - 3 } & $\begin{array}{l}\text { Std. } \\
\text { Deviation }\end{array}$ & 1.89297 \\
\hline $\begin{array}{l}\text { Most Extreme } \\
\text { Differences }\end{array}$ & Absolute & .220 \\
\cline { 2 - 3 } & Positive & .220 \\
\cline { 2 - 3 } & Negative & -.105 \\
\hline \multicolumn{2}{|l|}{ Kolmogorov-Smirnov Z } & 1.100 \\
\hline \multicolumn{2}{|l|}{ Asymp. Sig. (2-tailed) } & .178 \\
\hline
\end{tabular}

a Test distribution is Normal.

b Calculated from data.

Berdasarkan nilai test kelas kelas eksperimen (sesudah perlakuan) dengan skala likert hasil uji normalitas diketahui $0.178 \geq 0.05$, maka dapat disimpulkan bahwa nilai residual berdistribusi normal.

Berdasarkan hasil tes terhadap kelas control (sebelum perlakuan) dan hasil test kelas eksperimen (sesudah perlakuan) dalam SPSS.versi 11.5 terdapat nilai frekuensi kelas control (sebelum perlakuan) lebih rendah dari nilai frekuensi Kelas eksperimen (sesudah perlakuan) pada skala likert (Jarang $=2$ ), pada skala ini merupakan nilai yang paling mudah dibandingkan dari nilai skala yang lain. Berikut adalah table nilai frekuensi antara kelas control (sebelum perlakuan) dengan kelas eksperimen (sesudah perlakuan) pada skala likert (Jarang) dengan nilai 2.

Pada nilai skala likert (2) yang artinya (Jarang) dan menjadi nilai tertinggi di kedua kelas, nilai ini dapat menjandi pembanding antara kelas control (sebelum perlakuan) dengan kelas ekperimen (sesudah perlakuan) dikarenakan lebih sering muncul di kedua kelas tersebut. Pada kelas control (sebelum perlakuan) nilai tes frekuensi $\leq$ nilai tes frekuensi kelas eksperimen yang sudah diberikan perlakuan sehingga hal ini dapat simpulkan bahwan pemberian perlakuan terhadap kelas eksperimen memberikan dampak positif terhadap siswa kelas tersebut karena pada kelas ekperimen yang diberika perlakuan banyak yang jarang melakukan tindakan dari tiga bentuk perilaku bullying kecuali pada bullying Fisik masih terdapat perilaku bullying yang tinggi.

Pada hasil uji independen Sampel T-test (uji t) diketahui bahwa nilai signifikasi $0.123 \geq 0.05$, maka terdapat nilai yang signifikan antara kelas control (sebelum perlakuan) dengan kelas eksperimen (sesudah perlakuan). Sehingga untuk menguji hipotesis maka dapat dilihat dari nilai signifikasi 2 tailled yaitu Ho diterima jika sig. 2 tailled $\geq 0.05$ dan Ho ditolak jika sig. 2 tailled $\leq 0.05$. Jadi hipotesis dari penelitian ini Ho diterima karena nilai sig 2 tailled $\geq 0.05$ yaitu $(0.123 \geq 0.05)$. Maka pada penelitian ini terdapa peranan guru PPKn dalam menangani perilaku bullying siswa di SMPN 2 Tinambung.

\section{KESIMPULAN}

1. Pada nilai skala likert (2) yang artinya (Jarang) dan menjadi nilai tertinggi di kedua kelas, nilai ini dapat menjandi pembanding antara kelas control (sebelum perlakuan) dengan kelas ekperimen (sesudah perlakuan) dikarenakan lebih sering muncul di kedua kelas tersebut. Pada kelas control (sebelum perlakuan) nilai tes frekuensi $\leq$ nilai tes frekuensi kelas eksperimen yang sudah diberikan perlakuan sehingga hal ini dapat simpulkan bahwan pemberian perlakuan terhadap kelas eksperimen memberikan dampak positif terhadap siswa kelas tersebut karena pada kelas ekperimen yang diberika perlakuan banyak yang jarang melakukan tindakan dari tiga bentuk perilaku bullying kecuali pada bullying Fisik masih terdapat perilaku bullying yang tinggi.

2. Pada hasil uji independen Sampel T-test (uji t) diketahui bahwa nilai signifikasi $0.123 \geq 0.05$, maka terdapat nilai yang signifikan antara kelas control (sebelum perlakuan) dengan kelas eksperimen (sesudah perlakuan). Sehingga untuk menguji hipotesis maka dapat dilihat dari nilai signifikasi 2 tailled yaitu Ho diterima jika sig. 2 tailled $\geq 0.05$ dan Ho ditolak jika sig. 2 tailled $\leq 0.05$. Jadi hipotesis dari penelitian ini Ho diterima karena nilai sig 2 tailled $\geq 0.05$ yaitu $(0.123 \geq 0.05)$. Maka pada penelitian ini terdapa peranan guru PPKn dalam menangani perilaku bullying siswa di SMPN 2 Tinambung.

3. Pada hasil tes wawancara guru PPKn di SMPN 2 Tinambung yaitu beliau mengatakan bahwa dalam materi pembelajaran PPKn merupakan materi yang menanamkan nilai akhlak yang mulia dan nilai moral yang berkarakter serta membina dan membimbing siswa menjadi lebih baik. Namun dalam menangani perilaku agresif (bullying) siswa tidak ada program khusus yang 
dijalanka akan tetapi beliau berusaha melakukan peer mentoring dan juga memberikan bimbingan sesaat sebelum proses kegiatan belajar mengajar

4. Pada hasil tes wawancara guru BK di SMPN 2 Tinambung untuk mengetahui peranan guru PPKn dalam menangani perilaku bullying siswa di SMPN 2 Tinambung, Beliau mengatakan peranan seorang Guru PPKn dalam menangani perilaku bullying sangat berperan karena dalam pengalaman memahami karakter siswa tidak dapat diragukan sehingga kita sama-sama focus membimbing siswa ketika memiliki masalah. Adapun program khusus dalam menangani perilaku bullying misalnya ketika seorang siswa datang memberikan laporan bahwa ia telah mengalami perlakuan yang kurang baik dari siswa lain, maka beliau sebagai guru BK memanggil siswa tersebut dan memberikan nasihat bahwa perilaku tersebut tidak pantas untuk dilakukan. Dan jika siswa tersebut masih melakukan hal itu, maka sesuai prosedur akan diberikan surat peringatan.

5. Pada hasil tes wawancara siswa-siswi pada kelas control (tidak ada perlakuan) di SMPN 2 Tinambung untuk mengetahui peranan guru PPKn dalam menangani perilaku bullying siswa di SMPN 2 Tinambung. Hasilnya masih banyak siswa yang belum mengetahui pengertian dan bentuk dari perilaku Bullying, sebagiannya menganggap bahwa perilaku Bullying merupakan suatu candaan yang wajar. Sehingga peranan guru PPKn dalam perilaku Bullying sangat diperlukan di kelas control agar mencegah terjadinya hal-hal yang kurang menyenangkan yang dialami siswa di dalam ruang lingkup sekolah.

6. Pada hasil tes wawancara siswa-siswi pada kelas eksperimen (ada perlakuan) di SMPN 2 Tinambung untuk mengetahui peranan guru PPKn dalam menangani perilaku bullying siswa di SMPN 2 Tinambung. Hasilnya sangat baik karena sudah banyak siswa yang mengetahui pengertian dan bentuk perilaku bullying. Sehingga hal ini dapat mencegah terjadinya tindakan bullying yang ada di kelas Eksperimen.
Adapun peranan guru PPKn dalam menangani perilaku bullying yang mereka ketahui bahwa seorang guru PPKn sangat berperan terhadap perilaku bullying karena guru PPKn mampu mengenali karakter setiap individu sehingga dalam menangani perilaku

\section{DAFTAR PUSTAKA}

[1] Ariesto. (2009). Faktor - faktor penyebab bullying . jurnal bullying dalam dunia pendidikan (online). (http//www.stkipsiliwangi. ac. Id, diakses 20 desember 2017),

[2] Best. (2008). Metode penelitian (online), (http://repo.lain -tulung agung ac.id //revisi PDF, diakses 23 desember2017)

[3] Hadari Nawawi. (2007). Metode Penelitian Dibidang Social, Yogyakarta :gadja madah university Press

[4] Joshep, Lord Jim. (2008). Social support. Oxford university. (19-20)

[5] Kunandar, (2012), guru profesinal implementasi kurikulum tingkat satuan pendidikan (KTSP) dan sukses dalam sertifikasi guru, Jakarta: rajawali pers

[6] Laksono Tanjung. D. (2011). Self Ofriented. Forum penelitian. 1(1):5.

[7] Nova ardy wiyani, (2012). Save our children from school bullying ;yagyakarta:Ar-ruz media

[8] Nu'ma soemantri (2011). Defenisi pendidikan IPS. http. Lalabudianti.blogspot.com (31 agustus 2018)

[9] Olweus, Dan. (2002). Bullying at school: What We Know, What We Can Do. Massachusets: Blackwell Publisher.

[10] Pratama, (2016). Upaya guru bimbingan dalam mencegah perilaku bullying pada siswa SMAN colomadu, jawa tengah. Universitas Muhammadiyah Surakarta.

[11] Resis supiyani. (2016). Efektivitas layananan informasi dalam mereduksi perilaku bullying didalam dunia pendidikan. Lampung. Intstitut agama islam negeri raden intan lampung.

[12] Sahid rahardjo. (2014). Analisis korelasi. Spss for windows. http/www.konsistensi.com (04 september2018)

[13] Suci budiarti , (2013). Peran guru pendidikan kewarganegaraan dalam mencegah terjadinya perilaku bullying pada siswa (studi kasus di SMK muhammadiyah 1 surakarta). Universitas Muhammadiyah Surakarta.

[14] Sugiyono. (2010) Metodologi Penelitian Pendidikan: pendekatan kuantitatif, kualitatif, dan R\&D. Bandung: Alfabet,

[15] Suharsimi Arikunto. (2006) "Prosedur Penelitian Suatu Pendekatan Praktik penelitian pemula". Yogyakarta:

[16] Undang Undang RI No. 20 Tahun 2003 Tentang System Pendidikan Nasional . 
[17] Undang-undang RI Nomor 14 tahun 2005 tentang guru dan dosen. Tentang system pendidikan nasional.

[18] Widiyangto, joko. 2012. Spss for windows. Surakarta; badan penerbit fkip Unismuh surakarta 